\title{
The Influence of Work-Life Balance, Servant Leadership, and Reward to Employee Engagement with Job Satisfaction as Mediator
}

\author{
Andyan Pradipta Utama ${ }^{1 *}$, Tri Ratna Murti ${ }^{2}$, Netty Merdiaty ${ }^{3}$ \\ ${ }^{1)}$ Faculty of Economic and Business, Mercu Buana University, \\ 2) Faculty of Psychology, Universitas Persada Indonesia YAI \\ ${ }^{3)}$ Faculty of Psychology, Bhayangkara University \\ 1'andyanpradipta@mercubuana.ac.id, ${ }^{2}$ tri_rm@yahoo.com, ${ }^{3}$ netty.merdiaty@dsn.ubharajaya.ac.id
}

Article History: Received: 11 January 2021; Accepted: 27 February 2021; Published online: 5 April 2021

\begin{abstract}
The purpose of this research is to test the influence of work and personal balance, servant leadership, the reward of employee engagement with job satisfaction variables as mediators. The type of research used is explanatory research with a quantitative approach. The research hypothesis is a theoretical model consisting of the influence of work-life balance, servant leadership, and reward with mediator job satisfaction that can be used to predict and explain the emee engagement (FIT) with empirical data. The research respondent is the employee of Bank X in Bandung as much as 205 employees while the method of measuring data using a work-life balance scale, servant leadership and reward as an exogenous with a mediator job satisfaction to the employee engagement as endogenous with RMSEA 0.049. Data analysis using structural equation model (SEM) by using linear structural model (LISREL) version 8.72. Hypothesis testing structural relations included 5 variables fit, has the meaning the model matched (FIT) with field data. Hypothesis testing the structural relationship variables of the work-life balance, servant leadership, and reward simultaneously were able to describe the KK variable by 0.80 or $80 \%$, while the relationship of job satisfaction against employee engagement 0.42 or $42 \%$. The model accepted and the statement about the relationship of a variety of variables used is valid as a construct and can be inferred as the structural relationship.
\end{abstract}

Keywords: Job satisfaction, work, and personal balance, servant leadership, reward, and employee engagement

\section{INTRODUCTION}

The concept of employee engagement is not well known. A similar concept that is often used and well known to many individuals is the concept of job satisfaction that has been widely used in various companies. The concept of attachment and the concept of satisfaction is not much different, however, the concept of attachment is considered more important than the concept of satisfaction, because this factor encourages employees to do their maximum effort beyond what is expected, even this attachment factor is also able to influence the employee's decision to stay or leave the company, satisfaction work only encourages personal commitment, whereas employee engagement encourages mutual commitment. This is the meaning of attachment to the company, namely the existence of a joint commitment between the company and its employees and their work which will eventually acquire attachment.

On the other hand, said that attachment itself is influenced by various variables, one of which is the job satisfaction felt by employees, the higher the satisfaction felt by employees, the higher the attachment. Another factor that triggers attachment is when employees know their job career path clearly, and give appreciation in the form of non-extrinsic rewards, namely recognition of their existence in the organization, in addition to attracting employees to become attached, namely by offering activities and initiatives that are in line with natural competitive nature. employees rather than continually rewarding or rewarding them with financial incentives.

McLeod (2009) stated that the embedded organization has authentic strength and values, with clear evidence of trust and fairness based on mutual respect, where both have promises and commitments between superiors and employees that are understood and fulfilled. From the employee's perspective, personal relationships with direct superiors and leadership style and strategy are key. The attitudes and actions of superiors immediately become role models for employees which can ultimately increase attachment or vice versa create an atmosphere in which employees become detached. What's more, for both gene $\mathrm{Y}$ and gen $\mathrm{X}$, the leader's ability to receive input, directing and monitoring correctly and openly as well as superior communication techniques regarding the state of the organization are important things for employees in getting satisfaction in the organization. The leader's function is to move followers to follow or carry out what the leader orders or wants. Certain individuals are born with talents as leaders, but there are also those whose leadership traits are created in the process. However, the qualities of a leader are generally obtained and shaped not in an instant, but through a process that requires time and effort. Certain individuals are born with talents as leaders, but there are also those whose leadership traits are created in the process. However, the qualities of a leader are generally obtained and shaped not in an instant, but 
through a process that requires time and effort. Certain individuals are born with talents as leaders, but there are also those whose leadership traits are created in the process. However, the qualities of a leader are generally obtained and shaped not in an instant, but through a process that requires time and effort.

According to Robertson-Smith \& Markwick (2009), the characteristics of servant leader behavior grow from individual values and beliefs. Personal values such as fairness and integrity are independent variables that drive the behavior of serving leaders. Servant leadership is a type or style of leadership developed to overcome the leadership crisis experienced by the community or nation. Servant leadership has advantages because the relationship between the leader and subordinates is oriented towards the nature of serving with spiritual-moral standards. Leaders who have this characteristic have a responsibility to serve the interests of their subordinates to be more prosperous. Servant leadership can be applied to all professional fields, organizations, institutions, companies, and government because it is service and universal. Serving leaders can influence productivity in real organizational situations.

Greenleaf (2002) stated that servant leadership is service-oriented, knowledge-based, participatory, process, ethical and social responsibility aspects, which can ease scandals or conflicts in organizations. The high number of employees who leave gen $Y$ can hinder the company from developing, if it continues, the company will experience losses which have an impact on the recruitment, selection, training, and development process of employees, as well as in terms of corporate social dynamics, it has an impact on reducing cohesiveness within the team morale, can even increase conflict among employees (Kuean et al., 2010). Leave employees can also have a negative impact on company administration and can affect the financial and social conditions of the work environment (Butali, Wesang'ula,

Gen Y employees are often confused about their desires and their work and even their hobbies. Generation Y needs a balance between their work and their roles (work-life balance) in their social life. Research by Ummu (2011), shows that employees with conflicting personal and work needs are several times more likely to suffer from mood swings, anxiety, and addictive substance abuse disorders than employees without a need conflict. On the other hand, Ivancevich (2010) say that role conflict occurs when an individual's compliance with a set of expectations regarding a job conflict with adherence to another set of expectations. Therefore, there needs to be an effort to balance work and life,

Employees who focus on mastery of skills rather than rewards will be more enthusiastic about their work. A focus on personal improvement and skill development keeps motivation high in the long run. Mastery of expertise is one of the motivational factors that come from within the person himself, namely intrinsic motivation. There were differences in research results regarding the effect of reward and recognition on attachment. The research results of Nusatria \& Suharnomo (2011) show that appreciation and recognition affect employee attachment, while Saragih \& Margaretha (2013) that appreciation and recognition do not affect employee attachment.

Based on the background of the above problems, the authors are interested in researching the effect of balance between work and personal and serving and rewarding leaders on the attachment of gen Y employees with job satisfaction mediators.

\section{LITERATURE REVIEW Employee Engagement}

Employee attachment is a psychological state of employees, in which employees feel an interest in the success of the company and are motivated to improve their performance beyond the required work standards. Employee attachment can also be defined as employees' positive behavior towards the organization as well as the value that employees have towards the organizations involved and being aware of the business context and working with colleagues to improve performance for the benefit of the organization. Saks (2006) stated that employee attachment is a multi-aspectual form of emotional, cognitive, and physical aspects of employees that are intertwined and is one of the concepts developed from positive psychology and positive organizational behavior.

Robertson-Smith \& Markwick (2009) stated that employees can be divided into three types related to the level of employee attachment, namely employees who are attached, not attached, and active but not attached. Employees who have attachments will work with passion and feel a deep connection with the company. Meanwhile, employees who do not have attachments will work such as walking while sleeping throughout the working time, working with always thinking about the end of working hours, and not contributing more to the company. In the third category, active employees who do not have attachment are not only unhappy in their work, 
employees actively show that they do not like their work, even to the point of messing with the work of other employees who have an attachment.

Based on some of the opinions above, what is meant by employee attachment is a positive attitude that employees have with full meaning, as well as high motivational energy, having a desire to try, with full concentration on the task.

\section{Job satisfaction}

Job satisfaction is a form of individual feeling and expression when able or unable to meet the expectations of the work process and performance. According to Robbins (2013), job satisfaction is a positive feeling about the job that results from an evaluation of its characteristics. Job satisfaction is a pleasant emotional state that results from job appraisal or work experience and is the way employees feel about themselves or their work or personal conditions.

Mathis \& Jackson (2001) stated that job satisfaction is a positive emotional state which is the result of evaluating individual work experiences. Job satisfaction arises based on an assessment of the work situation, an assessment is made of one of his jobs as a sense of appreciation in achieving important values at work. Satisfied employees prefer their work situation rather than dislike them. Feelings related to job satisfaction and dissatisfaction tend to reflect the employee's interpretation of his current and past work experiences rather than his expectations for the future.

Based on the various opinions above, it can be concluded that job satisfaction is the feeling of pleasure of employees towards various aspects of their work.

\section{Work and personal balance}

Work and personal balance are defined as a personal balance between life at work and other lives as social beings. The meaning of balance here is not the same as based on quantity or quantity, but it means more psychologically, of course, it will be different from one individual to another. Balance in the context of this research does not always take the form of a scale. For example, employees who are not married and who are married work outside the city and live separately from their families, for those who are not married this will not have an impact on their personal life, but for those who are married, living separately from their families has an imbalance in their personal life. because there is a family to watch out for. So that the size becomes very different, for that there is no right size whether it is balanced or not because each individual has different life and priorities in his life. Therefore, the company must think about the work and personal balance strategy that is implemented in its company by understanding the needs of its employees which of course differ from one employee to another and understanding the balance desired or needed by its employees.

Dundas stated (in Noor 2011) that work and personal balance in the effective management of work and other important activities such as family, community activities, volunteer work, personal development, tourism a,nd recreation.

Based on the opinions of the experts above, what is meant by work and personal balance is an individual's perception of his ability to be able to balance employee time in two places, namely the work environment and the environment outside of work.

\section{Serving leaders}

Serving leaders are leaders who are humble, prioritizing sincerity, honesty with their own selves. Modesty means keeping things as simple as possible, without the slightest bit of emotional stress. As stated by Walters (2000), the modesty of a leader can also be grown if individuals want to see their role as merely serving other individuals. The main priority of the servant leader is how to develop followers, internal community, and externals, not to be selfish.

According to Lantu et al., (2007) the concept of serving leaders emphasizes the importance of respecting humans as God's creatures so that leaders assume that empowerment and development of followers is a mandate that must be fulfilled. Follower development, which means that prioritizing other individuals is a basic character of servant leadership. This is done by using actions and words that show followers are priority, placing the interests and successes of followers above the leader's interests and successes. 
Based on some of the opinions above, what is meant by serving leadership is a leader who prioritizes individual appreciation and development, builds community and shows authenticity.

\section{appreciation}

Awards are all things obtained in the form of money, goods, directly or indirectly received by employees as rewards or services provided to companies (Hasibuan, 2007). The joining of an individual in a company or organization as a member is certainly accompanied by various expectations that their needs can be met by the company, in return for their participation in the achievement of some of the company's goals, the company makes it possible to pay its employees more than just a salary or basic wage, but it is also possible to provide various allowances, as well as awards, both material and non-material according to their respective achievements.

Awards must be given at the right time, and should be given after the employee has performed the performance that should have been rewarded. If not given immediately, the award will lose the impact of the moment of truth as a motivator. The impact of the award must be felt in the long term and can produce more value if the feeling of happiness generated by the award lasts long in the recipient's memory. Awards must be changeable, award givers are often wrong in setting awards and some award decisions are more difficult to change than others. Rewards require an efficient cost that is able to motivate employees as expected by the company with minimum costs.

Based on some of the opinions above, in this study what is meant by award is the reward given in both material and non-material form which the company provides to its employees.

\section{Generation Y}

According to Tulgan \& Martin (2001) Generation Y is a generation born in 1978, while according to Howe $\&$ Strauss (2000) generation Y is a generation born in 1982, this occurs because of differences in the schemes used to classify these generations. because these researchers came from different countries.

Generation $\mathrm{Y}$ is the generation that dominates the world of work in Indonesia and abroad today. Generation $\mathrm{Y}$ is a group of young people born in early 1980 to early 2000 (Horowitz, 2013). Generation Y is a generation that often applies creativity and focuses on self-development so they tend to choose jobs that are fun and tend to have fun (Maharani et al., 2015) The formation of generation Y cannot be separated from the role of previous generations. Generation $\mathrm{Y}$ is formed from the development of technology and information science. Previous researchers said that there was a similarity between the general portrait of Y generation in Indonesia and the demographic figures in the US and Europe

Lyons \& Rogers (2004) stated that the characteristics of generation Y are the characteristics of each individual is different, depending on where he was raised, the economic and social strata of the family, as well as communication patterns, fanatical social media users and their lives are very much affected by technological developments, more open to political and economic views, so that generation Y looks very reactive to the changes in the environment that occur around them, has more attention to wealth.

\section{Framework}

The relationship between variables to be tested in this study can be illustrated in the theoretical model below:

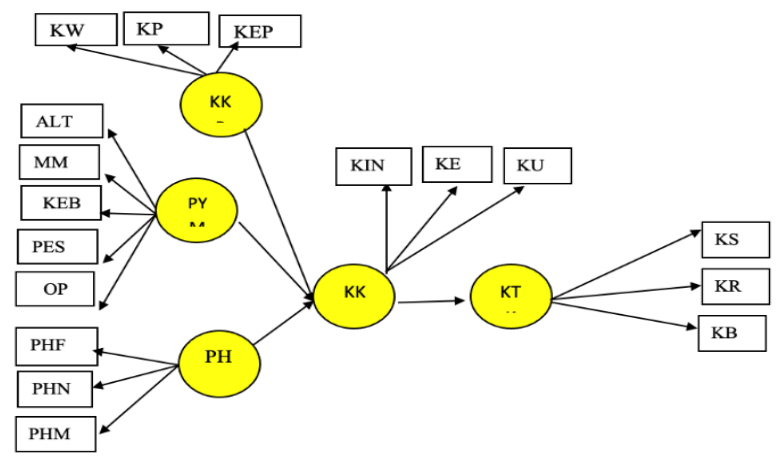

Figure 1. Theory Model 
Information:

\section{KTK: Employee Engagement}
a. $\quad \mathrm{KS}=$ Readiness
b. $\mathrm{KR}=$ Willingness
c. $\mathrm{KB}=$ pride

\section{KK: Job Satisfaction}
a. $\quad \mathrm{KIN}=$ Intrinsic satisfaction
b. $\mathrm{KE}=$ Extrinsic Satisfaction
c. $\mathrm{KU}=$ general satisfaction

3. KKP: Work and Personal Balance
a. $\mathrm{KW}=$ Time balance
b. $\mathrm{KP}=$ Balance of roles
c. $\mathrm{KEP}=$ The balance of satisfaction

\section{PYM: Serving Leader}
a. $\quad$ ALT $=$ Altruistic call
b. $\mathrm{MM}=$ Emotional healing
c. $\mathrm{KEB}=$ Wisdom
d. $\quad \mathrm{PES}=$ Persuasive mapping
e. $\mathrm{OP}=$ Service organization

\section{PH: Award}
a. $\mathrm{PHF}=$ Financial reward
b. $\mathrm{PHM}=$ Appreciation attached
c. $\quad \mathrm{PHN}=$ Non-financial award

\section{Research Hypothesis}

Based on the literature review that has been described, in general it can be said that work and personal balance as well as leaders who serve and reward in this study as dependent or exogenous variables, affect employee attachment as an independent or endogenous variable and job satisfaction variables as a mediator or intervening. as follows:

Based on of a theoretical model of the relationship between variables, then the hypothesis of this study is

1. There is an influence of work and personal balance, a leader who serves on employee attachment and rewards with job satisfaction variables as a mediator fit with empirical data on gen Y employees at BANK X in Bandung

2. There is an effect of job satisfaction as a mediator on employee attachment to gen $Y$ employees at BANK X in Bandung

3. There is an effect of work and personal balance on employee engagement with job satisfaction as a mediator for gen Y employees at BANK X in Bandung.

4. There is the influence of a leader serving on employee engagement with job satisfaction as a gen $\mathrm{Y}$ employee mediator at BANK $\mathrm{X}$ in Bandung.

5. There is an effect of appreciation on employee engagement with job satisfaction as a mediator for gen $\mathrm{Y}$ employees at BANK $\mathrm{X}$ in Bandung.

\section{RESEARCH METHODS}

The method of measuring the data of this study uses a scale of work and personal balance, serving leaders and rewards as exogenous with job satisfaction mediators of employee attachment as endogenous with RMSEA 0.049. Data analysis used the Structural Equation Model (SEM) using the Linear Structural Model (LISREL) version 8.72. Testing the structural relationship hypothesis which includes the 5 fit variables means that the model is fitted with the field data. The hypothesis testing of the structural relationship between work and personal balance variables, 


\section{RESULTS AND DISCUSSION}

\section{Employee engagement scale.}

Confirmatory factor analysis (CFA), an indicator that contributes to the latent variable of employee engagement is shown in table 1 below:

Table 1.

Employee Attachment Scale Validity Test

\begin{tabular}{lcc}
\hline Variable & Standardize loading factor (SLF) $\geq 0.50$ & Significancy \\
\hline CFA & & \\
KS & 1.00 & Significant \\
KR & 0.91 & Significant \\
KB & 0.97 & Significant \\
\hline
\end{tabular}

Source: Primary Data 2019

Based on table 1, it can be seen that the standardized loading factor

$\geq 0.50$ it can be said that the validity of the observed variables is good. Reliability measurement aims to determine the reliability of respondents in each aspect and the variance of the extract to determine the amount of variance/construct formed by each aspect. To measure the two tests, SLF results and measurement errors were obtained on the CFA.

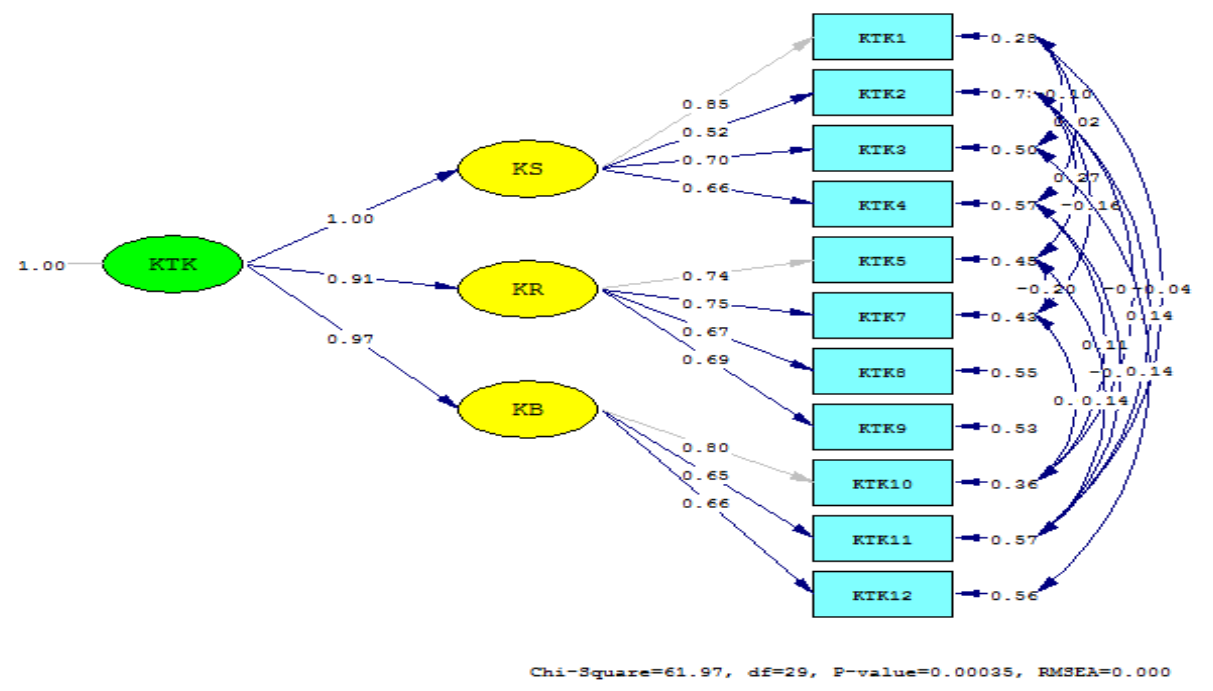

Figure 2: Employee Attachment Path

Information:

$\mathrm{KS}=$ Readiness, $\mathrm{KR}=$ Willingness, $\mathrm{KB}=$ Pride. Based on the path diagram (standardize), the validity of employee engagement, the results of the reliability test of the employee attachment scale are as shown in table 2 below:

Table 2.

Reliability of constructs and variance of extract reliability

\begin{tabular}{cccc}
\hline Indicator & SLF $(\lambda)$ & $\lambda 2$ & Measurement Error $[(1-(\lambda 2))]$ \\
\hline KTK1 & 0.85 & 0.7225 & 0.1275 \\
KTK2 & 0.52 & 0.2704 & 0.2496 \\
KTK3 & 0.70 & 0.4900 & 0.2100 \\
KTK4 & 0.66 & 0.4356 & 0.2244 \\
KTK5 & 074 & 0.5476 & 0.1924 \\
KTK7 & 0.75 & 0.5625 & 0.1875 \\
KTK8 & 0.67 & 0.4489 & 0.2211 \\
KTK9 & 0.69 & 0.4761 & 0.2139 \\
\hline
\end{tabular}




\begin{tabular}{cccc}
\hline \hline \multicolumn{1}{l}{} & & \\
\hline KTK10 & 0.80 & 0.6400 & \\
KTK11 & 0.65 & 0.4225 & 0.1600 \\
KTK12 & 0.66 & 0.4356 & 0.2275 \\
\hline$\sum$ & 7.69 & 5.3706 & 0.2244 \\
\hline
\end{tabular}

\section{Source: Primary Data 2019}

The value of construct reliability is as follows:

$\left(\sum \lambda\right) 2$

$\mathrm{CR}=$ $=0.96$

$\left[\left(\sum \lambda\right) 2+\sum(\varepsilon)\right]$

$\mathrm{PC}$ value $=0.96$

Value for Variance Extracted $(\mathrm{VE})=\sum \lambda 2 / \sum \lambda 2+\sum \varepsilon=0.69$

Based on the calculation, the construct reliability value is 0.96 which means that the employee attachment reliability is 0.96 while the variance extracted value is to show the variance of the VE 0.69 aspect is the same as the standard set by CR which is $\geq 0.70$ and $\geq 0.50$ for VE (Setyohadi, 2006 in Kusnendi, 2008) the CR and VE assessment results for employee attachment are reliable. This means that the aspects contained in the measurement model are composite and consistent can measure the latent variable of employee attachment

Table 3.

GOF (Goodness of Fit Structural Model) Employee Engagement Scale

\begin{tabular}{cccc}
\hline GOF size & Decision criteria & Value count & Information \\
\hline Satorra-Bentler & small value & $24.41(\mathrm{P}=0.71)$ & \\
Scaled Chisquare & $\mathrm{p}>0.05$ & & Good \\
RMSEA & $\leq 0.08$ & 0.042 & Good \\
GFI & $\geq 0.90$ & 0.95 & Good \\
AGFI & $\geq 0.90$ & 0.88 & Moderate \\
NFI & $\geq 0.90$ & 0.99 & Good \\
NNFI & $\geq 0.90$ & 1.00 & Good \\
\hline
\end{tabular}

Source: Primary Data 2019

Based on the results of the above analysis, it shows that all measurement models meet the fit criteria based on the predetermined fit index and the magnitude of the numbers has been mentioned above for each instrument involved in the study. Based on the results of this analysis, it can be concluded that all measurement models can be accepted as fit models with data from the field. Therefore a significance test can be carried out.

\section{Job Satisfaction Scale}

Confirmatory factor analysis (CFA), aspects that contribute to latent variables of employee satisfaction are as shown in Figure 3 below:

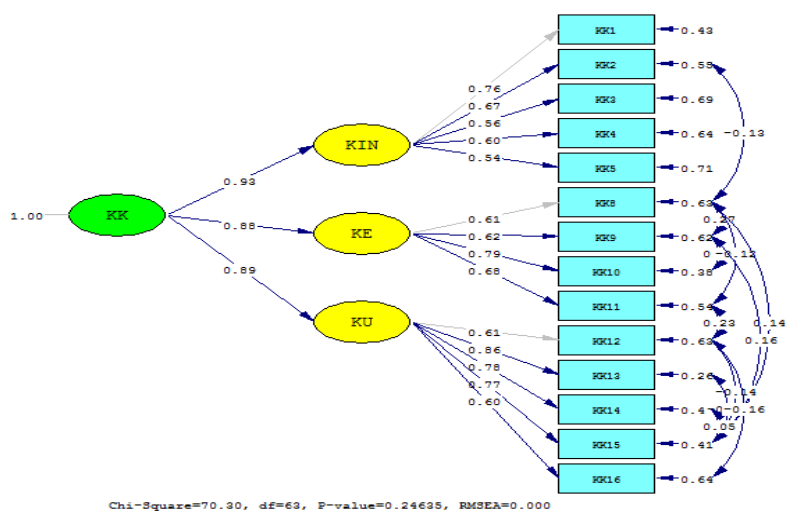

Figure 3: Path to the Employee Satisfaction scale 
Information: KIN = Technical Satisfaction KE = Extrinsic Satisfaction KU = General Satisfaction

Based on the Path Diagram (Standardize), the validity of forming employee satisfaction, the results of the validity and reliability test of the employee satisfaction scale are as shown in table 4 below:

Table 4

Validity Test of Job Satisfaction Scale

\begin{tabular}{lll}
\hline Variable & Standardize loading factor (SLF) $\geq 0.50$ & Significancy \\
\hline CFA & & \\
KS & 0.93 & Significant \\
KR & 0.88 & Significant \\
KB & 0.89 & Significant \\
\hline
\end{tabular}

Source: Primary Data 2019

Based on table 4, it can be seen that the standardized loading factor of $\geq 0.50$ says that the validity of the observed variables is good. Reliability measurement aims to determine the reliability of respondents in each aspect and the variance of the extract to determine the amount of variance/construct formed by each aspect. To measure the two tests, the SLF results and measurement error at CFA were obtained as in table 5 below:

Table 5

Construction Reliability and Extrak Reliability Variance

\begin{tabular}{cccc}
\hline Indicator & SLF $(\lambda)$ & $\lambda 2$ & Measurement Error $[(1-(\lambda 2))]$ \\
\hline KK1 & 0.76 & 0.5776 & 0.1824 \\
KK2 & 0.67 & 0.4489 & 0.2211 \\
KK3 & 0.56 & 0.3136 & 0.2464 \\
KK4 & 0.60 & 0.36 & 0.24 \\
KK5 & 0.54 & 0.2916 & 0.2484 \\
KK8 & 0.61 & 0.3721 & 0.2379 \\
KK9 & 0.62 & 0.3844 & 0.2356 \\
KK10 & 0.79 & 0.6241 & 0.1659 \\
KK11 & 0.68 & 0.4624 & 0.2176 \\
KK12 & 0.61 & 0.3721 & 0.2379 \\
KK13 & 0.86 & 0.7396 & 0.1204 \\
KK14 & 0.78 & 0.6084 & 0.1716 \\
KK15 & 0.77 & 0.5929 & 0.1771 \\
KK16 & 0.60 & 0.36 & 0.24 \\
\hline$\sum$ & 9.45 & 6,5077 & 2.9423 \\
\hline
\end{tabular}

Source: Primary Data 2019

The value of construct reliability is as follows:

$$
\begin{array}{r}
\left(\sum \lambda\right)^{2} \\
\mathrm{CR}==0.97 . \\
{\left[\left(\sum \lambda\right) 2+\sum(\varepsilon)\right]}
\end{array}
$$

Value for Variance Extracted $(\mathrm{VE})=\left(\sum \lambda 2\right)$

$$
\left(\sum \lambda 2\right)+\sum \varepsilon
$$

$$
=0.68
$$

Based on the calculation, the construct reliability value is 0.97 which means that the employee satisfaction reliability is 0.97 while the extracted variance value is 0.68 to show the variance of the $\mathrm{VE}$ aspect $=$ with the standard set by CR is $\geq 0.70$ and $\geq 0.50$ for VE (Setyohadi, 2006 in Kusnendi, 2008), the results of CR and VE assessments for job satisfaction are reliable. This means that the aspects contained in the measurement model are composite and consistent can measure the latent variable of job satisfaction. The suitability of the variables in the study can be seen in table 6 below: 
Table6.

Gof (Goodness of Fit Structural Model)Employee satisfaction scale

\begin{tabular}{cccc}
\hline GOF size & Decision criteria & Value count & Information \\
\hline Satorra-Bentler Scaled & small value & $70.30(\mathrm{P}=0.25)$ & Good \\
Chi-Square & $\mathrm{p}>0.05$ & 0.27 & Good \\
RMSEA & $\leq 0.08$ & 0.95 & Good \\
GFI & $\geq 0.90$ & 0.92 & Good \\
AGFI & $\geq 0.90$ & 0.98 & Good \\
NFI & $\geq 0.90$ & 1.00 & Good \\
NNFI & $\geq 0.90$ &
\end{tabular}

Source: Primary Data 2019

\section{Work and Personal Balance Scale}

Confirmatory factor analysis (CFA), an indicator that contributes to the latent variables of work and personal balance is as illustrated in Figure 4 below:

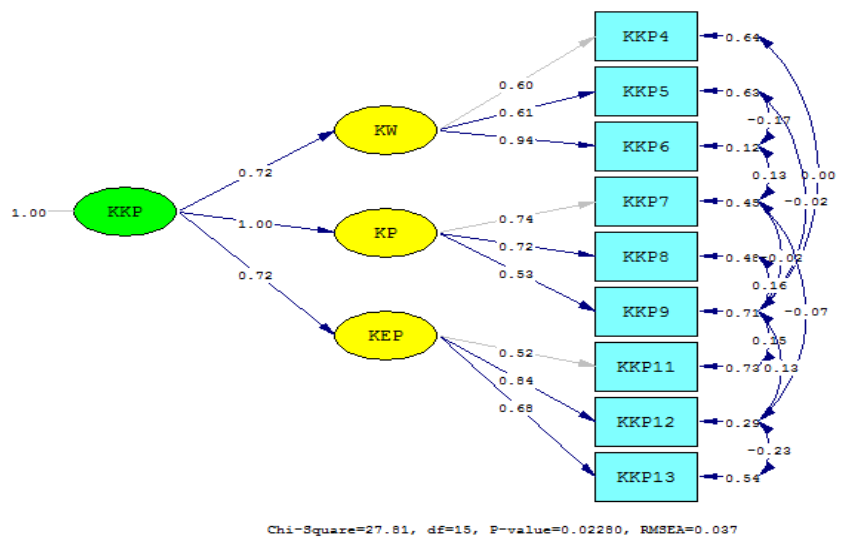

Figure 4: Path of work and personal balance

Note: $\mathrm{KW}=\mathrm{KW}$ balance $=$ Role balance. $\mathrm{KEP}=$ Satisfaction Balance

Based on the Path Diagram (Standardize), it is the validity of forming job and personal satisfaction, so the results of the validity and reliability test are as shown in table 7 below:

Table 7.

Validity Test of work and personal balance variables.

\begin{tabular}{|c|c|c|}
\hline Variable & Standardize loading factor (SLF) $\geq 0.50$ & Significancy \\
\hline \multicolumn{3}{|l|}{ CFA } \\
\hline KW & 0.72 & Significant \\
\hline $\mathrm{KP}$ & 1.00 & Significant \\
\hline KEP & 0.72 & Significant \\
\hline
\end{tabular}

Source: Primary Data 2019

Based on table 21, it can be seen that the standardized loading factor of $\geq 0.50$ can be said that the validity of the observed variables is good. Reliability measurement aims to determine the reliability of respondents in each aspect and the variance of the extract is to determine the amount of variance/construct formed by each aspect. To measure the two tests, the SLF results and measurement error at CFA were obtained which are in table 8 below:

\section{Table 8.}

Reliability of the constructand Variance of Extrak Reliability

\begin{tabular}{llll}
\hline Indicator & $\operatorname{SLF}(\lambda)$ & $\lambda 2$ & Measurement Error $[(1-(\lambda 2))]$ \\
\hline KKP4 & 0.6 & 0.36 & 0.64 \\
KKP 5 & 0.61 & 0.3721 & 0.6279 \\
KKP6 & 0.94 & 0.8836 & 0.1164 \\
KKP7 & 0.74 & 0.5476 & 0.4524 \\
\hline
\end{tabular}




\begin{tabular}{llll}
\hline \hline \multicolumn{1}{l}{} & & \\
\hline KKP8 & & & \\
KKP9 & 0.72 & 0.5184 & 0.4816 \\
KKP 11 & 0.53 & 0.2809 & 0.7191 \\
KKP12 & 0.52 & 0.2704 & 0.7296 \\
KKP13 & 0.84 & 0.7056 & 0.2944 \\
\hline$\sum$ & 0.68 & 0.4624 & 0.5376 \\
\hline
\end{tabular}

Source: Primary Data 2019

The value of construct reliability is as follows:

$$
\mathrm{CR}=\frac{\left(\sum \lambda\right) 2}{\left.L\left(\sum \lambda\right) 2+\sum(\varepsilon)\right]}=0.95
$$

Value for Variance Extracted $(\mathrm{VE})=\left(\sum \lambda 2\right) /\left(\sum \lambda 2\right)+\sum(\varepsilon)=0.71$

Based on the calculation, the construct reliability value is 0.95 which means that the reliability of work and personal balance is 0.95 while the variance extracted value of 0.71 is to show that the variance of the VE aspect is the same as the standard set by CR which is $\geq 0.7$ percent and $\geq 0.50$ for VE (Setyohadi, 2006 in Kusnendi, 2008), the results of CR and VE assessments for work and personal balance are reliable. This means that the aspects contained in the measurement model are composite and consistent can measure the latent variables of work and personal balance. The suitability of the variables in the study can be seen in table 9 below:

Table 9.

GOF (Goodness of Fit Structural Model) scale work and personal balance

\begin{tabular}{cccc}
\hline GOF size & Decision criteria & Value count & Information \\
\hline Satorra-Bentler Scaled & small value & $19.28(\mathrm{P}=0.20)$ & Good \\
Chi-Square & $\mathrm{p}>0.05$ & 0.080 & Good \\
RMSEA & $\leq 0.08$ & 0.97 & Good \\
GFI & $\geq 0.90$ & 0.91 & Good \\
AGFI & $\geq 0.90$ & 0.98 & Good \\
NFI & $\geq 0.90$ & 0.99 & Good \\
NNFI & $\geq 0.90$ & 2019
\end{tabular}

Source: Primary Data 2019

\section{Serving Leader Scale}

Confirmatory factor analysis (CFA), aspects that contribute to the latent variable of serving leaders as depicted in figure 6 below

Description: $\mathrm{ALT}=$ Altruistic Call MM = Emotional Healing KEB = Wisdom. PES = Persuasive Mapping. $\mathrm{OP}=$ Service Organization.

Based on the path diagram (standardize), the validity of serving leaders, the validity and reliability test results can be seen in table 10 below:

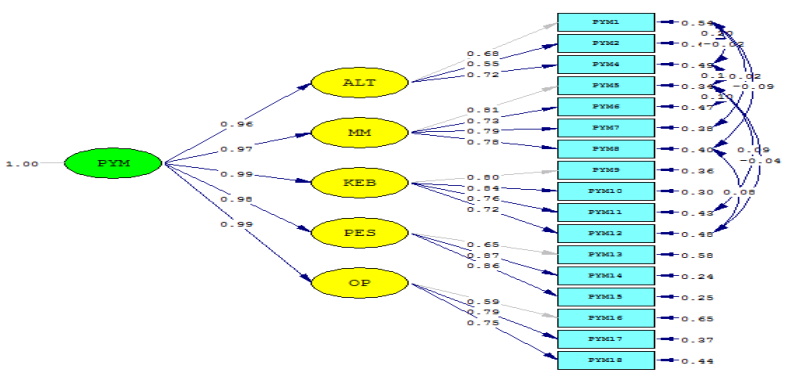

Figure 5.

Table 10

Test the Validity of the Serving Leader Variable

$\begin{array}{lll}\text { Variable } & \text { Standardize loading factor (SLF) } \geq 0.50 & \text { Significancy }\end{array}$




\begin{tabular}{ccc}
\hline CFA & & \\
ALT & 0.96 & Significant \\
MM & 0.97 & Significant \\
KEB & 0.99 & Significant \\
PES & 0.98 & Significant \\
OP & 0.99 & Significant \\
\hline
\end{tabular}

\section{Source: Primary Data 2019}

Based on table 10 , it can be seen that the standardized loading factor $\geq$ of 0.50 can be said that the validity of the observed variables is good. Reliability measurement aims to determine the reliability of respondents in each aspect and the variance of the extract is to determine the amount of variance/construct formed by each aspect. To measure the two tests, the SLF results and measurement errors are obtained as shown in table 11 below:

Table 11.

Construction Reliability and Extrak Reliability Variance

\begin{tabular}{|c|c|c|c|}
\hline INDICATOR & SLF $(\lambda)$ & $\lambda 2$ & MEASUREMENT ERROR $[(1-(\lambda))]$ \\
\hline PYM1 & 0.68 & 0.4624 & 0.5376 \\
\hline PYM2 & 0.55 & 0.3025 & 0.6975 \\
\hline PYM4 & 0.72 & 0.5184 & 0.4816 \\
\hline PYM5 & 0.81 & 0.6561 & 0.3439 \\
\hline PYM6 & 0.73 & 0.5329 & 0.4671 \\
\hline PYM7 & 0.79 & 0.6241 & 0.3759 \\
\hline PYM8 & 0.78 & 0.6084 & 0.3916 \\
\hline PYM9 & 0.80 & 0.6400 & 0.3600 \\
\hline PYM10 & 0.84 & 0.7056 & 0.2944 \\
\hline PYM11 & 0.76 & 0.5776 & 0.4224 \\
\hline PYM12 & 0.72 & 0.5184 & 0.4816 \\
\hline PYM13 & 0.65 & 0.4225 & 0.5775 \\
\hline PYM14 & 0.87 & 0.7569 & 0.2431 \\
\hline PYM15 & 0.86 & 0.7396 & 0.2604 \\
\hline PYM16 & 0.59 & 0.3481 & 0.6519 \\
\hline PYM17 & 0.79 & 0.6241 & 0.3759 \\
\hline PYM18 & 0.75 & 0.5625 & 0.4375 \\
\hline$\sum$ & 12.69 & 9,6001 & 3.0899 \\
\hline
\end{tabular}

Source: Primary Data 2019

The value of construct reliability is as follows:

$$
\begin{gathered}
\mathrm{CR}=\left(\sum \lambda\right) 2=0.98 \\
{\left[\left(\sum \lambda\right) 2+\sum((\varepsilon)\right.}
\end{gathered}
$$

Value for Variance Extracted $(\mathrm{VE})=\left(\sum \lambda 2\right) \quad=0.75$

$$
\left(\sum \lambda 2\right)+\sum(\varepsilon)
$$

Based on the calculation, the construct reliability value is 0.98 which means the reliability of the serving leader is 0.93 , while the Variance Extracted value is 0.75 to show that the variance of the VE aspect is the same as the standard set by CR is $\geq 0.70$ percent and $\geq 0.50$ for VE (Setyohadi, 2006 in Kusnendi, 2008), the results of CR and VE assessments for serving leaders are reliable. This means that the aspects contained in the measurement model in a composite and consistent manner can measure the latent variables that form serving leaders. The suitability of the variables in the study can be seen in table 26 below:

Table 12

GOF (Goodness of Fit Structural Model) scale serving leaders

\begin{tabular}{llll}
\hline GOF size & Decision criteria & Value count & Information \\
\hline Satorra-Bentler Scaled & small value & $68.04(\mathrm{P}=0.00099)$ & Good \\
Chi-Square & $\mathrm{p}>0.05$ & & Good \\
RMSEA & $\leq 0.08$ & 0.042 & \\
\hline
\end{tabular}




\begin{tabular}{llll}
\hline \hline & & & \\
& & & \\
\hline GFI & $\geq 0.90$ & 0.90 & Good \\
AGFI & $\geq 0.90$ & 0.84 & Marginal \\
NFI & $\geq 0.90$ & 0.98 & Good \\
NNFI & $\geq 0.90$ & 0.99 & Good \\
\hline
\end{tabular}

Source: Primary Data 2019

\section{Award Scale}

Confirmatory factor analysis (CFA), indicators that contribute to the latent variable of appreciation are shown in Figure 6 below:
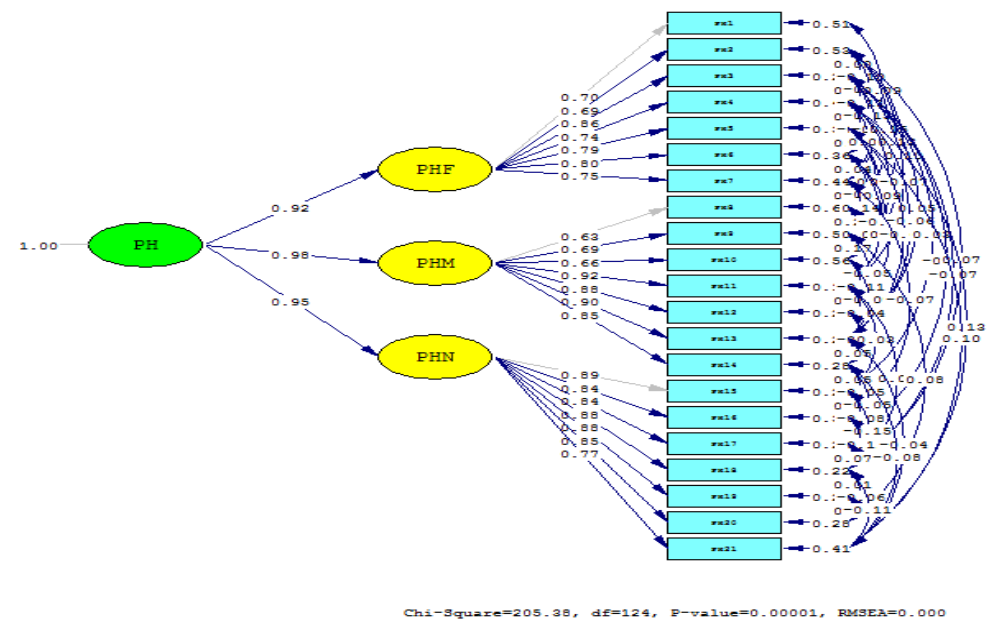

Figure 6. Path standardize reward scale

Caption of Figure 6: PHF = Financial Award. $\mathrm{PHM}=$ Appreciation attached. $\mathrm{PHN}=$ Non-Financial Award

Based on the Path Diagram (Standardize), based on the 5 path diagram (standardized), the results of the validity and reliability test of the award scale are as shown in table 12 below.

Table 12.

Award Variable Validity Test

\begin{tabular}{llr}
\hline Indicator & Standardize loading factor (SLF) $\geq 0.50$ & Significancy \\
\hline CFA & & \\
PHF & 092 & Significant \\
PHM & 0.98 & Significant \\
PHN & 0.95 & Significant \\
\hline
\end{tabular}

Source: Primary Data 2019

Based on table 12 above, with a standardized loading factor $\geq 0.50$, it can be said that the validity of the observed variables is good. Reliability measurement aims to determine the reliability of respondents in each aspect and the variance of the extract is to determine the amount of variance / construct formed by each aspect. To measure the two tests, the SLF results and measurement error at CFA were obtained which are shown in table 13 below:

Table 13

Construction Reliability and Extrak Reliability Variance

\begin{tabular}{lllc}
\hline Indicator & SLF $(\lambda)$ & $\lambda 2$ & Measurement Error $[(1-(\lambda 2))]$ \\
\hline PH1 & 0.7 & 0.49 & 0.51 \\
PH2 & 0.69 & 0.4761 & 0.5239 \\
PH3 & 0.86 & 0.7396 & 0.2604 \\
PH4 & 0.74 & 0.5476 & 0.4524 \\
PH5 & 0.79 & 0.6241 & 0.3759 \\
PH6 & 0.8 & 0.64 & 0.36 \\
PH7 & 0.75 & 0.5625 & 0.4375 \\
PH8 & 0.63 & 0.3969 & 0.6031 \\
\hline
\end{tabular}




\begin{tabular}{llll}
\hline \hline & & & \\
\hline PH9 & 0.69 & 0.4761 & \\
PH10 & 0.66 & 0.4356 & 0.5239 \\
PH11 & 0.92 & 0.8464 & 0.5644 \\
PH12 & 0.88 & 0.7744 & 0.1536 \\
PH13 & 0.9 & 0.81 & 0.2256 \\
PH14 & 0.85 & 0.7225 & 0.19 \\
PH15 & 0.89 & 0.7921 & 0.2775 \\
PH16 & 0.84 & 0.7056 & 0.2079 \\
PH17 & 0.84 & 0.7056 & 0.2944 \\
PH18 & 0.88 & 0.7744 & 0.2944 \\
PH19 & 0.88 & 0.7744 & 0.2256 \\
PH20 & 0.85 & 0.7225 & 0.2256 \\
PH21 & 0.77 & 0.5929 & 0.2775 \\
\hline$\sum$ & 15.42 & 12.6432 & 0.4071 \\
\hline
\end{tabular}

Source: Primary Data 2019

The value of the award construct reliability is as follows:

$$
\mathrm{CR}=\frac{\left(\sum \lambda\right) 2}{\left[\left(\sum \lambda\right) 2+\sum(\varepsilon)\right]}=0.98
$$

Value for Variance Extracted $(\mathrm{VE})=\left(\sum \lambda 2 \quad=0.63\right.$

$$
\left(\sum \lambda 2\right)+\sum \varepsilon
$$

Based on the calculation, the construct reliability value is 0.96 which means that the award reliability is 0.95 while the extracted variance value is to show the variance of the VE aspect of 0.63 according to the standard set by CR which is $\geq 0.70$ percent and $\geq 0.50$ for VE (Setyohadi, 2006 in Kusnendi, 2008), the results of CR and VE assessments for awards are reliable. This means that the items contained in the measurement model are composite and can consistently measure the latent variable of appreciation. The suitability of the variables in the

\begin{tabular}{|c|c|c|c|}
\hline GOF size & Decision criteria & Value count & Information \\
\hline $\begin{array}{l}\text { Satorra-Bentler Scaled } \\
\text { Chi-Square }\end{array}$ & small value $p>0.05$ & $222.70(\mathrm{P}=0.00)$ & Good \\
\hline RMSEA & $\leq 0.08$ & 0.00 & Good \\
\hline GFI & $\geq 0.90$ & 0.91 & Good \\
\hline AGFI & $\geq 0.90$ & 0.84 & Marginal \\
\hline NFI & $\geq 0.90$ & 0.99 & Good \\
\hline NNFI & $\geq 0.90$ & 1.00 & Good \\
\hline
\end{tabular}
study can be seen in table 14 below:

Table 14

GOF (Goodness of fit Structural Model) Award

Source: Primary Data 2019 


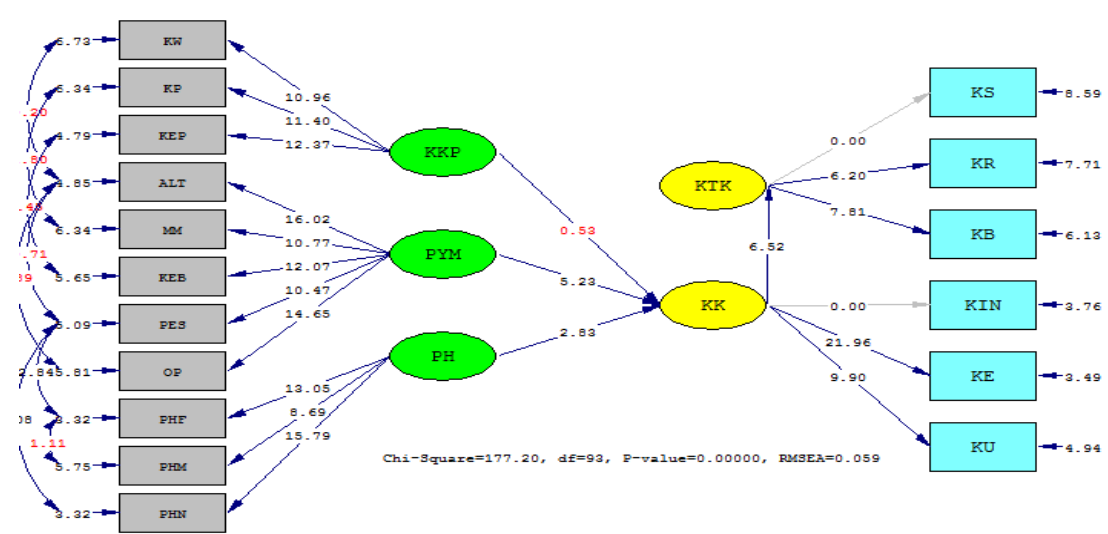

\section{Hypothesis test}

Figure 7: Path Hybrid Model T Value

\section{Overall Model Evaluation}

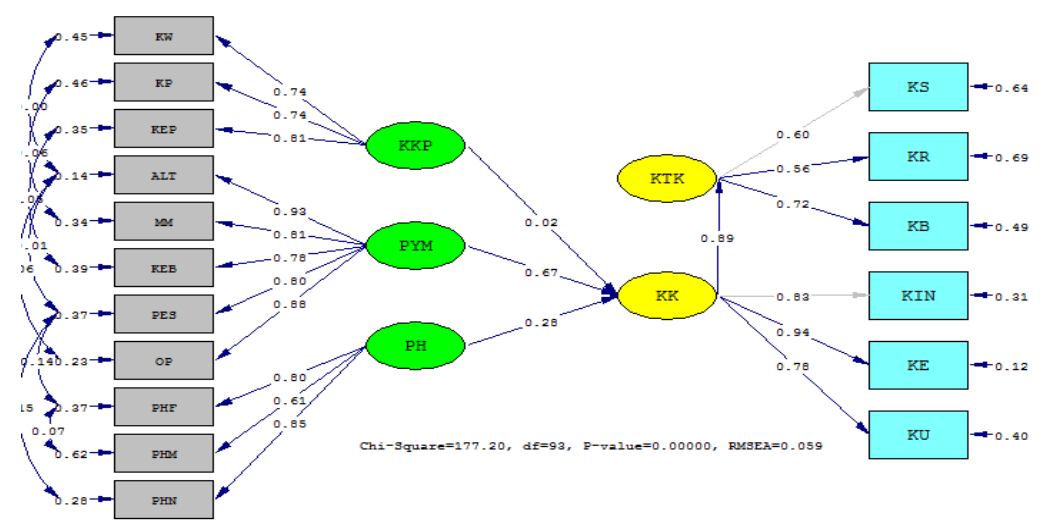

Figure 8: Path Hybrid Standardized Model

In the model fit test (GoF), it concludes that the model is acceptable, meaning that the model obtained can be used to test predetermined research hypotheses. By using the robust maximum likelihood estimation method, the analysis is completed as in table 15 below:

Table 15

Evaluation Result of GoF Hybrid From Research Model

\begin{tabular}{llll}
\hline GOF size & Decision Criteria & Compute Value & Information \\
\hline Satorra-Bentler & Small value & $143.70(\mathrm{P}=0.0015)$ & Good \\
Scaled Chi-Square & $\mathrm{p}>0.05$ & & \\
RMSEA & $\leq 008$ & 0.049 & Good \\
GFI & $\geq 0.90$ & 0.91 & Good \\
AGFI & $\geq 0.90$ & 0.86 & Marginal \\
NFI & $\geq 0.90$ & 0.97 & Good \\
NNFI & $\geq 0.90$ & 0.99 & Good \\
\hline
\end{tabular}

Source: Primary Data 2019

The results of the overall fit model in Table 15 show that the overall compatibility index has met the good fit parameters, RMSEA, NFI, NNFI, GFI, all have a fit value, and the AGFI value has a marginal value. With this in mind, the model is feasible and meets the GoF so that overall it can be concluded that the estimated structural model is acceptable.

\section{Evaluate the suitability of the measurement model}

The results of the fit model test on the theoretical model show that the model has a fit index with the data. The result of the $t$ value $\geq 1.96$ according to some research experts, the minimum limit of $t$ value which is 
considered feasible in confirmatory research is not less than 1.96 (Hair, et al, 1998; Gozali, 2004). The reliability of the model is indicated by two measures, namely construct reliability and variance extracted, both measures have previously been proven valid and reliable. The test results can be seen in table 16 below;

Table 16

Significance test results and the load factor Hybrid model $(\mathbf{n}=\mathbf{2 0 5})$

\begin{tabular}{|c|c|c|c|c|c|c|}
\hline No. & Scale & $\begin{array}{l}\text { The value } \\
\text { of } t \text { count }\end{array}$ & $\begin{array}{l}\text { Factor } \\
\text { load }\end{array}$ & Error & CR & VE \\
\hline \multirow{4}{*}{1} & Employee Engagement & & & & \multirow{4}{*}{0.96} & \multirow{4}{*}{0.69} \\
\hline & $\mathrm{KS}$ & 0.00 & 0.60 & 0.64 & & \\
\hline & KR & 6.20 & 0.56 & 0.69 & & \\
\hline & KB & 7.81 & 0.72 & 0.49 & & \\
\hline \multirow{4}{*}{2} & Job satisfaction & & & & \multirow{4}{*}{0.97} & \multirow{4}{*}{$0 / 68$} \\
\hline & KIN & 0.00 & 0.83 & 0.31 & & \\
\hline & TO & 21.96 & 0.94 & 0.12 & & \\
\hline & MY & 9.90 & 0.78 & 0.40 & & \\
\hline \multirow{4}{*}{3} & Work and personal balance & 10.96 & & & \multirow{4}{*}{0.95} & \multirow{4}{*}{0.71} \\
\hline & KW & 1140 & 0.74 & 0.45 & & \\
\hline & KP & $\begin{array}{l}11.40 \\
1237\end{array}$ & 0.74 & 0.46 & & \\
\hline & KEP & 12.31 & 0.81 & 0.35 & & \\
\hline & Serving leaders & & & & \multirow{6}{*}{0.98} & \multirow{6}{*}{0.75} \\
\hline \multirow{5}{*}{4} & ALT & 16.02 & 0.93 & 0.00 & & \\
\hline & MM & 10.77 & 0.81 & 0.06 & & \\
\hline & KEB & 12.07 & 0.78 & 0.05 & & \\
\hline & PES & 10.47 & 0.80 & 0.37 & & \\
\hline & $\mathrm{OP}$ & 14.65 & 0.88 & 0.23 & & \\
\hline \multirow{4}{*}{5} & appreciation & & & & \multirow{4}{*}{0.98} & \multirow{4}{*}{0.63} \\
\hline & PHF & 13.05 & 0.80 & 0.37 & & \\
\hline & PHM & 8.69 & 0.61 & 0.62 & & \\
\hline & PHN & 15.79 & 0.85 & 0.28 & & \\
\hline
\end{tabular}

Source: Primary Data 2019

\section{Hypothesis testing of structural relationships}

From the various measures of fit mentioned above, it can be generally concluded that the overall fit is good. After the theoretical model fits (goodness of fit) as described above, then the structural relationship hypothesis testing between variables can be done by testing the structural relationship hypothesis between variables; Structural Equations

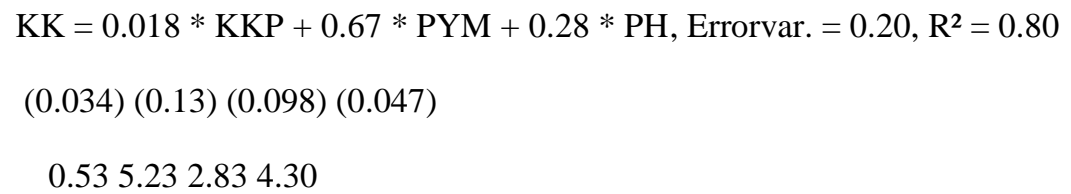

This means: PYM and PH significantly affect KN as indicated by the t-value of the two variables> 1.96, and one does not significantly affect the KKP variable. The three variables are simultaneously able to explain the variability of the KK variable by 0.80 or $80 \%$ so that the magnitude of the influence of other variables is $100 \%$ $80 \%=20 \%$

While the relationship between job satisfaction and employee attachment can be seen as follows:

$\mathrm{CEC}=0.89 * \mathrm{KK}$, Errorvar. $=0.58, \mathrm{R}^{2}=0.42$

(0.14) (0.17)

6.523 .43 
Meaning: KK significantly influences CEC as indicated by the $\mathrm{t}$ value of $6.52>1.96$, KK is able to be a mediator of 3 exogenous variables on CEC as endogenous by 56\%, so the magnitude of the influence of other exogenous variables not studied is $100 \%-42 \%=58 \%$.

With the acceptance of the model, the statement regarding the relationship between various constructs in this variable is a structural relationship, it can be seen in the equation above, it can be concluded that the research hypothesis is as follows:

\section{Major Hypothesis.}

Hypothesis testing of structural relationships that includes the 5 variable fit hypothesis can be accepted as a model that fits (fit) with data from the field. This means that the results obtained are "a theoretical model of the influence of work balance, serving leaders and rewards through job satisfaction as a mediator have an effect on employee engagement with work balance and personal fit, leaders serving fit, reward is fit ).

\section{1) Hypothesis 1.}

Job satisfaction on employee attachment from the results of data analysis obtained a t statistic of 6.52>1.96 and a standard loading factor of 0.89 , which means that employee satisfaction has a direct, positive and significant effect on employee attachment.

\section{2) Hypothesis 2.}

Work and personal balance on job satisfaction from the data obtained a statistical $t$ value of $0.53<1.96$ and $\beta 0.018$, which means that work and personal balance does not have a direct and positive effect on job satisfaction. It also seems that the influence of work and personal balance on attachment does not indirectly have a significant effect, the KKP towards the $\mathrm{KK}=0.013$, the $\mathrm{KK}$ to the $\mathrm{KTK}=0.79$ so that the KKP towards the $\mathrm{KK}=0.018 *$ $0.80=0.015$ and the direct effect of the KKP towards the KK is $(0.015) 2=0.0020$. It seems that work-personal balance has no direct or indirect effect on gen Y employee attachment to the organization.

\section{3) Hypothesis 3.}

Leaders who serve on employee satisfaction from the data obtained that the $t$ value is $5.23>1.96$ and $\beta$ 0.67 , which means that the leader who serves has a positive effect on job satisfaction. It seems that the influence of the serving leader on employee attachment is indirect, from PYM to KK $=0.67$, KK to KTK $=0.89$, so PYM to $\mathrm{KK}=0.67 * 0.89=0.5963$. It seems that the leader who serves to become attached to the organization must go through job satisfaction as a mediator.

\section{4) Hypothesis 4.}

Appreciation for job satisfaction from the data obtained t count of $2.83>1.96$ and $\beta 0.28$ have a significant positive effect on job satisfaction, meaning that rewards have a positive effect on job satisfaction. It seems that the effect of appreciation on employee attachment is indirect, from $\mathrm{PH}$ to $\mathrm{KK}=0.28$, KK to $\mathrm{KTK}=0.89$, so PYM to $\mathrm{KK}=0.28 * 0.89=0.2492$.

Thus full job satisfaction becomes a mediator of work and personal balance, a serving leader, and an appreciation for employee engagement.

\section{Discussion}

Of the four variables hypothesized in this study; Job satisfaction, work and personal balance, serving leaders and rewards are only three which are proven to have an impact and have a significant positive effect and one variable has an effect but is not positively significant on employee engagement through the mediator of job satisfaction. The explanation for this phenomenon is as follows:

Job satisfaction has a positive and significant impact on employee engagement, this means that higher job satisfaction encourages higher employee attachment which will eventually form an attitude or assessment of organizational excellence that is obtained so as to encourage working actively and forming a fanatical attitude that is relatively permanent in the long term. which is reflected by the item KIN (intrinsic satisfaction) iesatisfaction that is obtained when employees can successfully carry out their jobs properly. Wijono (2010) stated that job satisfaction is a pleasant feeling which is the result of individual perceptions in order to complete tasks or fulfill their needs to obtain work values that are important to themselves. This is confirmed by Locke in Wagner et al., 
(1995) that job satisfaction is a positive and pleasant emotional level. In other words, job satisfaction is a result of an individual's estimate of work or positive and pleasurable experiences.

The management of BANK $\mathrm{X}$ and all employees should increase the maximum cooperation between divisions, and foster a sense of empathy and sincerity of employees at work, so employees will feel responsible for their work and then feel that they can complete the job well. According to Arif \& Chohan (2012) that the level of employee job satisfaction is a manifestation of positive and negative feelings about the workplace and the job itself.

This opinion is in line with the opinion of Robbins, (2007) that job satisfaction is a general attitude of individuals towards their work. Work requires interaction with colleagues and superiors, following organizational rules and policies, meeting performance standards, living in working conditions that are often less than ideal, and other similar things. This means that the employee's assessment of satisfaction or dissatisfaction with work is a complex summation of a number of discrete elements of work that are separated from one another.

The concept of job satisfaction is pointed out as the main variable that has a continuous and linear impact that is beneficial for the HRD department to retain its employees. Because in forming attachment requires efforts from management in this case HRD to form employee satisfaction through several supporting factors, the respondent's response to the job satisfaction variable is $80 \%$ which is influenced by the 3 supporting variables, namely:

Work and personal balancehas a positive and insignificant impact on employee attachment through job satisfaction, which in turn will reduce attachment caused by dissatisfaction at work because they feel unattended for their balance and work, make employees become independent because they feel they do not have the freedom to manage work time according to their own needs as personal. According to Singh \& Khanna (2011), workpersonal balance is a broad concept that involves setting proper priorities between work, career and ambition, on the one hand, life, happiness, leisure, family and spiritual development on the other. Work and personal balance involves the ability of individuals to regulate the number of demands in life simultaneously,

Work and personal balance in general with regard to working time, flexibility, welfare, family, demographics, migration, leisure and so on, is essential. Not achieving work and personal balance results in low job satisfaction, low happiness, and employee burnout. Work and personal balance has a good content in work and also outside of work with minimal conflict (Godlif Christian Poeh, 2017) (Clarke et al., 2018).

Delivered by Boulding et al., (1993) that the occurrence of attachment to employees is due to the influence of satisfaction and dissatisfaction with work and personal balance that accumulates continuously in addition to perceptions of work quality, how to create a good work and personal balance in the minds of employees so that employees attached and fanatical to the organization. This concept was popularized by Lockwood in 2003, that work and personal balance is a balanced condition on two demands where work and life of employees are the same, where work and personal balance in the view of employees is the choice of managing work and personal obligations or family responsibilities. . Another case for the company view, This term is a challenge to form a supportive culture in the company, where employees can focus on their work in the workplace. The following is the explanation: In this study, the concept is tried to be applied with the consideration that if this concept is proven to work well it will provide a new perspective on employee attachment at BANK X. The results of research in the field show that work and personal balance shows that there is no significant impact on attachment through satisfaction. work. The concept of work and personal balance was initially considered a powerful enough strategy to get employees attached, elicitation in the field, especially in Gen Y at BANK X, there is an inverse theory when the concept of work and personal balance is applied to Gen Y employees, through job satisfaction the results are positive but not significant effect on attachment through job satisfaction.

Serving leaders have a positive and significant impact on employee attachment through job satisfaction which in turn will increase the attachment caused by job satisfaction with the influence of the serving leader giving a tendency to unconditional attachment, accepting deficiencies and continuing to contribute to the organization because they are sure, then will create a good perception This is reflected in the KEB (Wisdom) and OP (service organization) items, which describes the extent to which the leader prepares the organization to make positive contributions to its environment through community service and community development programs and encourages higher education as a community.

The following is the explanation: Servant leadership is a concept of ethical leadership introduced by Greenleaf (2002) in 1970 with his book entitled The Servant as Leader. The primary objective of Greenleaf's research and observations on servant leadership is to build a better and more caring society. Serving leaders are 
leaders who have a soul to serve their employees starting with natural feelings. This choice is made consciously and individually by a leader is natural feelings and urge to serve will naturally arise. This main thrust is what differentiates it from other leaders.

According to Spears (2010) (Anik Herminingsih, 2016), a leader who serves is a leader who prioritizes service, starting with the natural feeling of a leader who wants to serve who puts service first. Furthermore, consciously, this choice brings aspirations and encouragement in leading other individuals. Meanwhile, according to Trompenaars \& Voerman (2009), a serving leader is a management style in terms of leading and serving in harmony, and there is interaction with the environment. Serving leaders are leaders who have a strong desire to serve and lead, the most important thing is to be able to combine the two as things to strengthen each other in a positive way.

A striking difference can be seen from the main priorities of other individuals served. It can be seen from the results, whether the employees served grow become wiser, freer, more autonomous individuals, who are definitely more positive and able to pass on the principle of service itself to other individuals. Empirically, the role of the leader in BANK X has a very high contribution and has a significant effect on satisfaction, the significance value of the serving leader provides the largest contribution among the 3 other research variables that are tested on the formation of job satisfaction and then becomes the reinforcer for employee attachment to the organization

Appreciation has a significant positive impact on employee engagement through job satisfaction. This implies that the higher the reward provides higher satisfaction for employees and makes the level of attachment increases. The largest value of the award scale is reflected by the item PHM (embedded reward) is an allowance given to employees in the form of pride and empathy on the part of the company and PHN (non-financial award) awards or benefits provided to employees in non-monetary forms such as authority, appreciation and appointment of employees as company representatives

In this study, the concept of reward was tried to be applied in the formation of attachment through job satisfaction, this concept began to be popularized by experts, one of which was by Aaker in 1995, this concept is used with the consideration that if this concept works well, it will shape employee perceptions of job satisfaction. and influencing attachment, the reward is a reward given to motivate employees to have high productivity (Tohardi, 2002). The results of research conducted by the author at BANK $X$ prove that the data in the field states that rewards have a positive effect on employees at BANK X, the shift in employee perceptions is influenced by employees 'views of the institution and also employees' views on the quality of rewards at BANK X,

Awards are incentives that link pay on the basis of being able to increase employee productivity in order to achieve a competitive advantage (Simamora, 2004). The reward system is one of the many things that are very often discussed in organizations. Awards can affect organizational effectiveness, attract and at the same time remember employees as motivation in developing skills and performance. The award also aims to retain employees in the company from being targeted by other companies. Good and attractive awards are able to minimize the number of employees who leave the company to join other companies. According to Swansburg (2004), performance-based rewards can have a positive impact on employee behavior, lead to job satisfaction for employees,

\section{CONCLUSION}

On the basis of a theoretical model of the relationship between variables, then the hypothesis of this study is as follows:

1. There is an influence of work and personal balance, the leader who serves on employee attachment and rewards with job satisfaction variables as a fit mediator with empirical data on gen Y employees at BANK $\mathrm{X}$ in Bandung.

2. There is an effect of job satisfaction as a mediator on employee attachment to gen $\mathrm{Y}$ employees at BANK $\mathrm{X}$ in Bandung.

3. There is an effect of work and personal balance on employee engagement with job satisfaction as a mediator for gen Y employees at BANK X in Bandung.

4. There is the influence of a leader serving on employee engagement with job satisfaction as a gen $\mathrm{Y}$ employee mediator at BANK X in Bandung.

5. There is an effect of appreciation on employee engagement with job satisfaction as a mediator for gen $\mathrm{Y}$ employees at BANK X in Bandung. 


\section{REFERENCE}

1. Anik Herminingsih, K. (2016). The influence of training, work motivation and organizational culture on the performance of civil servants. Journal of Economic and Social Sciences, 5(3),241-257.

2. Arif, A., \& Chohan, A. (2012). How job Satisfaction is influencing the organizational citizenship behavior (OCB): A study on employees working in banking sector of Pakistan. Interdisciplinary Journal of Contemporary Research in Business, 4(8), 74-88.

3. Bilson, S. (2004). Panduan Riset Perilaku Konsumen, Jakarta: PT. Gramedia Pustaka Utama.

4. Boulding, W., Kalra, A., Staelin, R., \& Zeithaml, V. A. (1993). A dynamic process model of service quality: from expectations to behavioral intentions. Journal of Marketing Research, 30(1), 7-27.

5. Clarke, B., Swinburn, B., \& Sacks, G. (2018). Understanding health promotion policy processes: A study of the government adoption of the achievement program in Victoria, Australia. International Journal of Environmental Research and Public Health, 15(11). https://doi.org/10.3390/ijerph15112393

6. Godlif Christian Poeh, T. D. S. (2017). The influence of organizational commitment, job satisfaction and job stress on turnover intention school teacher in tangerang. Journal SWOT 7(2), 224-238.

7. Greenleaf, R. K. (2002). Servant leadership: A journey into the nature of legitimate power and greatness. Paulist Press.

8. Hasibuan, M. S. P. (2005). Manajemen sumber daya manusia, edisi revisi. Bumi Aksara, Jakarta, 288.

9. Horowitz, I. M. (2013). Synthesis of feedback systems. Elsevier.

10. Howe, N., \& Strauss, W. (2000). Millennials rising: The next great generation. Vintage.

11. Iswara, N. H. (n.d.). Dinamika Kesenian Gamelan pada Fungsi dan Pelestarian Kesenian Gamelan dalam Sanggar Budaya Singhasari di Kecamatan Singosari, Kabupaten Malang, Jawa Timur Noor Hidyat Iswara Abstrak Pendahuluan Kebudayaan adalah keselu- ruhan perilaku manusia dalam keh.

12. Ivancevich. (2010). Human resource management. McGraw-Hill International.

13. Kuean, W. L., Khin, E. W. S., \& Kaur, S. (2010). Employees' turnover intention to leave: The Malaysian contexts. The South East Asian Journal of Management, 4(2), 93-110.

14. Lantu, D., Pesiwarissa, E., \& Rumahorbo, A. (2007). Servant Leadership. Yogyakarta: Gradien Books.

15. Lyons, J. S., \& Rogers, L. (2004). The US child welfare system: A de facto public behavioral health care system. Journal of the American Academy of Child \& Adolescent Psychiatry, 43(8), 971-973.

16. Maharani, A., Femina, D., \& Tampubolon, G. (2015). Decentralization in Indonesia: lessons from cost recovery rate of district hospitals. Health Policy and Planning, 30(6), 718-727.

17. Mathis, R. L., \& Jackson, J. H. (2001). Manajemen sumber daya manusia. Thomson Learning.

18. Mello, J. A. (2006). Strategic human resource management. Thomson/South-Western.

19. Nusatria, S., \& SUHARNOMO, S. (2011). Employee Engagement: Anteseden dan Konsekuensi Studi pada Unit CS PT. Telkom Indonesia Semarang. Universitas Diponegoro.

20. Perilaku organisasi : konsep, kontroversi, aplikasi; Jilid 1 / Stephen P. Robbins; Hadyana Pujaatmaka, Benyamin Molan translator; (2003). Gramedia Jakarta.

21. Raymond Jr, M., \& Schell, G. P. (2001). Sistem Informasi Manajemen. Jakarta: Erlangga Offset.

22. Robbins, J. (2013). Beyond the suffering subject: toward an anthropology of the good. Journal of the Royal Anthropological Institute, 19(3), 447-462.

23. Robertson-Smith, G., \& Markwick, C. (2009). Employee engagement: A review of current thinking. Institute for Employment Studies Brighton.

24. Saragih, S. R., \& Margaretha, M. (2013). Anteseden dan konsekuensi employee engagement: studi pada industri perbankan.

25. Setyohadi, D. (2011). Pendekatan analitik untuk mengkaji stok ikan layang (Decapterus russelli) di Selat Madura. Indonesian Journal of Environment and Sustainable Development, 2(1).

26. Singh, P., \& Khanna, P. (2011). Work-life balance a tool for increased employee productivity and retention. Lachoo Management Journal, 2(2), 188-206.

27. Spears, L. C. (2010). Character and servant leadership: Ten characteristics of effective, caring leaders. The Journal of Virtues \& Leadership, 1(1), 25-30.

28. Tohardi, A. (2002). Pemahaman praktis manajemen sumber daya manusia. Universitas Tanjung Pura, Mandar Maju, Bandung.

29. Trompenaars, F., \& Voerman, E. (2009). Servant leadership across cultures: Harnessing the strength of the world's most powerful leadership philosophy. Infinite Ideas.

30. Tulgan, B., \& Martin, C. A. (2001). Managing Generation Y: Global citizens born in the late seventies and early eighties. Human Resource Development.

31. Wagner, J. A., Hollenbeck, J. R., \& Russell, J. (1995). Management of organizational behavior. Prentice Hall.

32. Wijono, S. (2010). Psikologi industri \& organisasi. Kencana. 